\title{
APRESENTAÇÃO
}

\section{VER MELHOR PARA COMPREENDER O PRESENTE E O PASSADO: 20 ANOS DE HISTÓRIA DA EDUCAÇÃO \\ DOI: http://dx.doi.org/10.1590/2236-3459/70035}

\author{
Maria Stephanou \\ Universidade Federal do Rio Grande do Sul, Brasil.
}

$\cos 80$

istória da Educação vem a público em seu número 51/2017 em meio a
tempos controversos, acontecimentos nacionais e internacionais
desconcertantes, o local e o global em suspensão porque em vertiginosa mudança. Os avanços e conquistas históricas que, no Brasil, acenavam projetos de futuro positivos no campo da Educação, como a inclusão curricular dos temas da diversidade e da multiculturalidade, assim como as políticas públicas de apoios e fomentos expressivos à escola pública brasileira, presentemente encontram-se ameaçados por processos multiformes e complexos. Nos últimos meses este campo encontra-se atravessado por pautas divergentes, disputas, lutas, projetos conflitantes: reforma do ensino médio, diretrizes curriculares nacionais, movimentos Escola sem Partido e Escola sem Mordaça, PEC 55 e redução drástica de investimentos públicos, além dos movimentos de ocupação de escolas de educação básica e universidades de diversas regiões do país, acontecimentos sem precedentes em nossa História da Educação.

O que nós, historiadores da Educação, podemos dizer, pensar, anunciar? O que nossas pesquisas sugerem e incitam a refletir sobre o que estamos assistindo no tempo presente?

A pauta de possibilidades de investimentos reflexivos e de formulação de alternativas de ação diante desses acontecimentos é extensa. Dentre as múltiplas frentes, tomemos o fio de uma inspiração para abrir caminho à reflexão, dentre as infinitas 
veredas possíveis, pois, afinal, como sugere Borges (1941), elas se bifurcam interminavelmente. Os tempos são texturas de nosso ser, fazer e viver a História e oferecem incontáveis possibilidades de devir.

O que queremos dizer com isso?

Abrir a história, instigante título do livro de Jean-François Sirinelli, historiador francês da história cultural política, foi traduzido para o português e publicado no Brasil em 2014. Nesta obra a página inicial está marcada por uma sugestiva epígrafe de Paul Valéry que, em 1932, escreveu com argúcia: "a história, temo, não nos permite prever; mas, associada à independência de espírito, pode nos ajudar a ver melhor."

Ver não é apenas e simplesmente o sentido da visão. Seria muito empobrecedor significá-lo assim. Paul Valéry afirma "ver melhor". Ver é ato em movimento, cambiante, calidoscópico, pensante e em intersecção ativa com ouvir, sentir, experimentar, tatear, pressentir, refletir e tantas outras potencias humanas de relação com o que nos é exterior e faz-se interior. Ver é um ato atravessado pelos regimes de luz: de onde se está e para onde se volta a mirada, de onde se situa aquele que vê, a refração da luz permite vislumbrar ou ocultar, (dis)por o olhar em uma determinada direção ou desvio, entre tantas e tantos possíveis. Em que consiste, aos historiadores da Educação, "ver melhor"? Ou, o que os historiadores da educação podem oferecer para que possamos "ver melhor"?

Referindo-se à História Política, que nos permitimos estender aqui à História da Educação, Sirinelli (2014) afirma que é preciso "ampliar o perímetro de análise", não reduzi-la nem às representações coletivas, nem aos fenômenos de percepção de uma consciência individual, tampouco pressupor um único e estável sentido das coisas atribuído pelos grupos que lhe são contemporâneos, ou uma dissociação do social, ou ainda, não podemos descuidar do fato de que precisamos nos debruçar sobre a análise dos processos variados de apreensão das realidades pelos indivíduos e pelos grupos (Sirinelli, 2014, p. 12).

Postos os argumentos acima, "ver melhor" constitui, para nós historiadores da educação, desafio certamente de grande monta, possivelmente em muitos momentos um temor, sobretudo pelos combates necessários à independência de espírito, antes apontada por Paul Valéry, que é sempre relativa, pois o historiador, ele mesmo, está ungido do social, suas disputas e seus regimes que se fazem verdadeiros a cada tempo.

Para que são escritas ou lidas as apresentações? São escritas por dever. Dever de memória. Dever de inscrição dos textos no tempo de sua publicação, no contexto de sua circulação como impresso. Neste presente, quiçá venham a ser lidos para "ver melhor". Ou, no futuro, oxalá constituam pistas dos pensamentos contemporâneos, indícios de nossas percepções do que sucede, dos nossos assombros diante da gravidade do momento e das mudanças no campo da Educação, sobretudo da educação pública.

Os textos enfeixados nesse número nos oferecem alguns pontos a partir dos quais podemos mirar o passado e o presente da Educação. Se alguns temas já são de longa tradição, estão repostos pelos autores na direção de novos olhares. Outros, ainda pouco explorados, abrem novas veredas de exercício investigativo no campo. Além disso, uma 
abertura cronológica e historiográfica vem se fazendo sentir nos últimos anos de História da Educação, com um comparecimento frequente de estudos vinculados aos estudos do tempo presente e uma maior atenção aos jogos de escalas de acontecimentos de diferentes níveis e dimensões.

Uma nota repetida, pela eloquência de seu significado na trajetória da revista, é a presença assídua de artigos escritos por pesquisadores estrangeiros, reforçando o caráter internacional que está, por assim dizer, no DNA deste periódico, sobretudo a cada dia mais consolidado como traço dos grupos de pesquisa dos pesquisadores do campo.

Este número 51 marca a trajetória de 20 anos, até o momento, de publicação ininterrupta da revista História da Educação, patrimônio do campo de estudos da área. Contemplamos neste número um conjunto que demarca com distinção a edição: uma sessão especial, com apresentação de nossa co-editora, profa. Maria Helena Camara Bastos, e uma singular e histórica entrevista com um dos pesquisadores de grande reconhecimento internacional no campo, o prof. dr. António Viñao Frago, atual professor e diretor do Centro de Estudios sobre la Memoria Educativa - Ceme, da Universidad de Murcia, Espanha. Suas contribuições aos estudos de história da alfabetização e da formação de professores conta com mais de 30 anos de circulação entre a comunidade de pesquisadores brasileiros de História da Educação. A apresentação lista suas publicações no Brasil e, particularmente, nesta revista.

Também apresentamos aos leitores um dossiê organizado pelos professores dr. Alberto Barausse, da Universitá degli Studi del Molise, Itália, e professora dra. Terciane Ângela Luchese, da Universidade de Caxias do Sul, Brasil, intitulado Da Itália ao Brasil: processos educativos e formativos, séculos 19 e 20, que examina as experiências e fatores que caracterizaram e acompanharam os processos de educação, de formação e cultura dos imigrantes italianos no Rio Grande do Sul e no Brasil nos séculos 19 e 20. Os apresentadores, Barausse e Luchese somam-se à observação de Myers (2009) para, aproveitando o ensejo do dossiê, alertar os historiadores da educação que pouca atenção foi dedicada pelo campo aos processos educativos entre imigrantes e minorias étnicas e que, neste caso, o dossiê retoma a reflexão historiográfica acerca da experiência histórica da imigração italiana no Brasil a partir da mirada aos processos educativos.

Integram o dossiê Da Itália ao Brasil cinco artigos. O primeiro, de autoria de Alberto Barausse, da Universitá degli Studi del Molise, Itália, intitula-se Focolari di educazione nazionale e di sentimento pátrio: le scuole italiane nel Rio Grande do Sul durante gli anni della colonizzazione di fine Ottocento (1875-1898), destaca o movimento pioneiro de escolas elementares étnicas, identificadas em documentos consulares, ainda pouco explorados pela historiografia da educação brasileira. O autor propõe uma reconstrução dessas experiências e destaca a heterogeneidade material, humana - corpo de professores - e curriculares das instituições escolares criadas nas colônias para garantir instrução e educação, mediante as crescentes demandas.

O artigo seguinte intitula-se Entraves no ensino da língua portuguesa nas escolas italianas privadas curitibanas e paulistanas (1883-1907). De autoria de Elaine Cátia Falcade Maschio, do Centro Universitário Autônomo do Brasil, e de Eliane Mimesse Prado, da Universidade de Caxias do Sul, focaliza a especificidade de escolas italianas, 
com subvenções do governo italiano, criadas no Estado do Paraná e em São Paulo, em contraste aos imperativos da nacionalização do ensino, em especial a criação de um corpo de inspetores.

Soma-se aos anteriores o artigo Per l'educazione patriottica e nazionale degli italiani all'estero: l'edizione postuma del libro di lettura O Patria mia di Luigi Bertelli (Vamba) e la sua diffusione in Brasile, escrito por Anna Ascenzi, da Universitá di Macerata, Itália, que reconstrói a gênese, os conteúdos e as filiações ideológicas e culturais, além da produção editorial, dentro e fora da península itálica, do livro de leitura para as escolas italianas no exterior no período entre guerras, intitulado O Patria mia do escritor para a infância Luigi Bertelli. O estudo apresenta um interesse particular por debruçar-se sobre o impresso que é considerado um dos mais notáveis e longevos livros de leitura para as escolas italianas.

O quarto artigo, de Terciane Ângela Luchese, da Universidade de Caxias do Sul, intitula-se Da Itália ao Brasil: indícios da produção, circulação e consumo de livros de leitura (1875-1945), livros estes em italiano enviados por sucessivos e distintos governos da Itália para as chamadas escolas italianas no exterior, incluindo o Brasil.

O artigo que finaliza o dossiê, Tra esigenze pastorali e impegno per la preservazione dell'identità nazionale: la Santa Sede e l'emigrazione italiana all'estero tra Otto e Novecento, é de autoria de Roberto Sani, pesquisador da Universitá di Macerata, Itália, e propõe a compreensão dos processos associados à imigração que orientaram um projeto institucional religioso, vinculado à Igreja Católica, durante os pontificados de Leão XIII e de Pio X, particularmente com relação à assistência e pastoral dos emigrados italianos no exterior.

A revista também está integrada por artigos de demanda espontânea, submetidos por pesquisadores individuais do campo da História da Educação. Estes abarcam um marco temporal amplo e contemplam temas como: arquivo pessoal de professor; História da Educação e relações sociais; discurso pedagógico e defesa do magistério; viagens educacionais; infância e discurso religioso; cultura material, espaços e edifícios escolares; escolas étnicas polonesas; laicismo e educação; associações científicas de História da Educação na América Latina; escolarização, territorialidade e espaço urbano; agentes do campo da educação; perfis profissionais e elites políticas.

Além disso, o numero 51 conta com uma resenha sobre história da imprensa periódica para a infância e a juventude italiana.

Cumpre registrar, por fim, que este volume conta com artigos de pesquisadores de cinco países, a saber: Argentina, Chile, Espanha, Itália, Venezuela. E do Brasil com os seguintes Estados: Minas Gerais, Rio de Janeiro, Rio Grande do Sul, Santa Catarina e São Paulo.

Neste ano de 2017, em que damos continuidade às duas décadas de edição e circulação da revista, convidamos a todos à leitura, apreciação, crítica e divulgação de nosso periódico, no intuito de que prossiga sendo um importante espaço de socialização e consolidação do campo da pesquisa, da docência e da formação em História da Educação. Um convite para ver melhor.

\section{Referências}

BORGES, Jorge Luís. El jardín de senderos que se bifurcan. Buenos Aires: Ficciones, 1941. 
SIRINELLI, Jean-François. Abrir a história: novos olhares sobre o século XX francês. Belo Horizonte: Autêntica 2014.

VALÉRY, Paul. Variété IV, 13 de julho de 1932. Paris: Gallimard, 1938, p.142.

MARIA STEPHANOU é professora titular da Faculdade de Educação da Universidade Federal do Rio Grande do Sul. Pesquisadora do CNPq, atua junto ao Programa de Pós-Graduação em Educação na linha de pesquisa História, memória e Educação. Doutora em Educação pela UFRGS, realizou seu pós-doutoramento junto ao Institut Français d'Éducation, IFÉ, França. Atua como co-editora de História da Educação desde 2011.

Endereço postal completo: Rua Dr. João Palombini, 144 A. 91751-150 - Porto Alegre - RS - Brasil.

E-mail: mastephanou@gmail.com.

Recebido em 13 de dezembro de 2016.

Aceito em 13 de dezembro de 2016. 